\title{
Cultivating forage maize for biomass and bioenergy in a sub-boreal climate
}

\author{
Kenedy E. Epie ${ }^{1,2}$, Olga M. Artigas ${ }^{1}$, Arja Santanen ${ }^{1}$, Pirjo S.A. Mäkelä ${ }^{1}$ and Frederick L. Stoddard ${ }^{1}$ \\ ${ }^{1}$ Department of Agricultural Sciences, P.O. Box 27, 00014 University of Helsinki, Finland \\ ${ }^{2}$ Present address: Montana State University, Western Triangle Agricultural Research Center (WTARC), USA \\ e-mail: etone.kenedy@montana.edu
}

\begin{abstract}
The biomass potential of eight high yielding maize cultivars was studied in the sub-boreal climate of southern Finland. The effects of harvest date on lignin and sugar production, biomass yield, mineral element composition, bioenergy potential and soil nutrient management were determined in two years. The eight maize cultivars produced 17.6-33.3 $\mathrm{t} \mathrm{ha}^{-1}$ of biomass. The ear fraction contained $50-60 \%$ of the biomass, and ash and mineral element composition of the plant fractions were significantly different $(p<0.001)$, with more ash, $\mathrm{Ca}$ and $\mathrm{S}$ in the above-ear fractions of the plants than in the mid-stalk portions, whereas the $\mathrm{C}: \mathrm{N}$ ratio was highest in the lower stalk. Cultivars with less lignin content produced more fermetable sugars. Despite the relatively cool growing conditions and short season of the sub-boreal region, maize has potential for use as biomass, for biofuel or other uses. The crop can be fractioned into ear and stalk, with the lower $20 \mathrm{~cm}$ of stalk left in the field to maintain soil organic matter content.
\end{abstract}

Key words: maize, plant fractions, biomass, bioenergy, sugar production, boreal climate

\section{Introduction}

Cropping options in the boreal and nemoral (sub-boreal) regions are restricted by the brevity of the growing season and the limited number of growing degree-days (heat sum) during the season. As in other marginal agricultural environments, year-to-year variation is great, with the limitation being exceptionally cool and damp summers (Peltonen-Sainio et al. 2016). Diversification of cropping systems is important for financial security of farms, and within the European Union, a farm must have at least three crop species to qualify for certain subsidies.

The boreal zone is defined by having a maximum of three months with a mean temperature above $10^{\circ} \mathrm{C}$ (Larsen 1980). When the baseline for calculating means was moved from 1960-1990 to 1970-2000, the Helsinki region gained a fourth month above that baseline, with September having a mean of $10.1^{\circ} \mathrm{C}$ (FMI 2017), placing it at the northern margin of the nemoral region.

Maize (Zea mays L.) is a warm-season crop that has seldom been grown in the boreal-nemoral zone. Its C4 metabolism apparently evolved in a warm, dry climate and is of little value in a cool climate (Sage 2004). Nevertheless, over a century of scientific plant breeding has increased its cool-weather tolerance to the extent that it is now a major crop in, among others, the United Kingdom. When it is grown as a silage crop, there is no need for its grain to mature to harvest-dryness. Furthermore, when grown for grain, the crop generates a huge quantity of stubble made of leaves and stalks of little commercial value (Barros-Rios et al. 2015). This vegetative biomass has been at the center of biofuel research (Byrt et al. 2011). It is readily available, not expensive and possibly yields up to five times more net energy per unit land area while emitting less greenhouse gases that would cause global warming (Farrell et al. 2006). Maize stubble could be combusted in Combined Heat and Power plants (CHP) (Bennett et al. 2007) and is considered a good feedstock option for bioethanol production (Chen et al. 2013). Quality factors such as ash content, mineral element composition, and the yield of soluble sugars determine its suitability for bioenergy, silage and other biomass uses. Earlier studies revealed that concentrations of mineral elements differed significantly between cultivars (Feil et al. 2005) Methane production is optimized when the carbon (C) to nitrogen $(\mathrm{N})$ ratio is between 10 and 30, and depends partly on cultivar (Amon et al. 2007).

In addition to grain and silage uses, maize has shown great potential for whole-crop bioenergy use in warm continental climates (Schittenheim 2008) and in boreal conditions (Seleiman et al. 2013). Pakarinen et al. (2011) used a conservative estimate of potential maize yield, just $15 \mathrm{t} \mathrm{ha}^{-1}$, in their determinations of potential biogas and bioethanol production. Oilseed rape (Brassica napus L. var. oleifera Metzg.) has been promoted as a biodiesel crop in central latitudes of Europe, but its high-latitude, short-season counterpart, turnip rape ( $B$. rapa L. ssp. oleifera [DC] Metzg.) yields less. Reed canary grass (Phalaris arundinacea L.) was promoted as a lignocellulose crop for bioenergy production in the Nordic region, but it has lost favour as the economic returns are often poor 
(Kukk et al. 2010, Lötjönen and Paappanen 2013). The European Union has established a series of targets for the use of renewable energy in which biofuels play an important part.

Cropping and harvesting all maize biomass with no replenishing strategy in place removes significant amounts of nutrients from the soil (Masters et al. 2016), reducing soil organic carbon (Huggins et al. 1998), so it affects nutrient content and water availability of soils (Doran 2002). Therefore, leaving and incorporating a fraction of the plant (about 30\%) into the soil is recommended (Wilhelm et al. 2004). Nutrient management studies on maize stubble have focused on quantifying the amount of nutrients removed by harvesting the whole crop (Masters et al. 2016), and few data exist on quantifying what is added when a fraction of the plant is recycled.

For these reasons, we investigated the potential for producing maize for whole-crop use at the junction of the boreal and nemoral zones. We tested the hypothesis that the crop should be given the longest possible growing period before harvest to maximize dry matter yield and evaluated the effect of harvest date on quality factors. We studied whether the crop should be harvested whole or divided into fractions (ear, above-ear, mid-stalk and lower stalk) to optimize yield and quality for heating or biogas production and soil nutrient management.

\section{Materials and methods}

Field trials were established in May 2010 and May 2011 at the Viikki Research Farm (60 13" N, 25 02" E; 3 m a.s.I.), University of Helsinki, Finland. The weather data were recorded at the Finnish Meteorological Institute (FMI), Kaisaniemi station, $9 \mathrm{~km}$ from the site. Both years were warmer than the long-term average, and 2010 was drier than average while 2011 was wetter (Table 1).

\begin{tabular}{|c|c|c|c|c|c|c|}
\hline \multirow[t]{2}{*}{ Month } & \multicolumn{3}{|c|}{ Mean air temperature $\left({ }^{\circ} \mathrm{C}\right)$} & \multicolumn{3}{|c|}{ Total monthly precipitation (mm) } \\
\hline & 1981-2010 & 2010 & 2011 & 1981-2010 & 2010 & 2011 \\
\hline May & 10.2 & 11.5 & 9.9 & 37 & 59 & 27 \\
\hline Jun & 17.8 & 14.6 & 16.7 & 63 & 33 & 49 \\
\hline Jul & 16.3 & 21.7 & 20.6 & 80 & 49 & 56 \\
\hline Aug & 15.8 & 18.1 & 17.5 & 79 & 97 & 173 \\
\hline Sep & 11.5 & 12.2 & 13.6 & 56 & 50 & 88 \\
\hline Oct & 6.6 & 6.0 & 8.5 & 76 & 29 & 69 \\
\hline Average/Total & 13.0 & 14.0 & 14.5 & 391 & 317 & 462 \\
\hline
\end{tabular}

Mokma et al. (2000) classified soils in the area as Sulfic Cryaquept (Soil Taxonomy), described as clay loam with rather high organic matter of 6-12\% DM, and pH 6.6. On 18 May in 2010 and 2011, eight cultivars, 'Amaretto', 'Campesino', 'Eleganza', 'Fabregaz', 'Fernandes', 'Ronaldinio', 'Respect' and 'Unity' (KWS Saat AG, Einbeck, Germany), were sown into plots $3.5 \mathrm{~m}$ wide and $8 \mathrm{~m}$ long. Plant spacing was $15 \mathrm{~cm}$ and row spacing was $70 \mathrm{~cm}$. The experiment was a randomized complete block design, with four replicates. Three weeks after seeding, the plots were were fertilized with $120 \mathrm{~N} \mathrm{~kg} \mathrm{ha}^{-1}$ (EY Lannoite NPK 16-7-13 Cemagro Oy, Lohja, Finland). Weeds were controlled on 15 June of both years using $2 \mathrm{~kg} \mathrm{ha}^{-1}$ Lentagran WP (pyridate $450 \mathrm{~g} \mathrm{~kg}^{-1}$, Belchim Crop Protection, Belgium).

To determine optimum harvest time in 2010, plant samples were collected three times, 128 (23 September), 143 (8 October), and 157 (22 October) days after seeding from $1.0 \mathrm{~m}^{2}$. The plants were cut at ground level and allowed to dry at room temperature for 15 days. Samples were weighed, chopped with a garden shredder (Garden Pro Line K290, Klippo, Germany), and then mixed well. Three subsamples were collected, weighed, dried in an oven at $105^{\circ} \mathrm{C}$ overnight, and weighed again. Dry samples were ground through a $0.5 \mathrm{~mm}$ sieve (ZM 200, Retsch $\mathrm{GmbH}$, Germany) for acid hydrolysis, and through a $2.0 \mathrm{~mm}$ sieve (ZM200) for enzyme hydrolysis and ash content. Samples were stored at $-20^{\circ} \mathrm{C}$ until analysis. The dry matter yield was calculated as average single plant dry matter multiplied by the number of plants per hectare.

To determine the partitioning of yield and nutrients in both years, plant stands were harvested from $1.0 \mathrm{~m}^{2}$ plots in October, 150-160 days after sowing. Plants were cut $10 \mathrm{~cm}$ above the soil surface, fractioned into ear, 
above-ear (head), mid-stalk (stalk below ear) and lower stalk (20 cm from cut), dried in an oven at $70{ }^{\circ} \mathrm{C}$ for 5 days and weighed. The weights of the dry plant fractions were added to obtain total biomass yield. Dried plant samples were chopped, and subsamples ground as described before and stored in air tight plastic containers until further analysis.

Ash content was determined by burning one gram of dried ground sample in a muffle furnace (LV 15/11/ P320, Nabertherm $\mathrm{GmbH}$, Germany) for $12 \mathrm{~h}$ at $575^{\circ} \mathrm{C}$. Chloride (Cl) was determined from $500 \mathrm{mg}$ of subsamples according to Mäkelä et al. (2003) using a chloride analyser (Chloride Analyzer 926, Sherwood Scientific Ltd., Cambridge England). Carbon and nitrogen contents were determined on subsamples of $200 \mathrm{mg}$ by the Dumas method in a Vario Max EL II CN Analyzer (Elementar Analysensysteme GmbH, Germany) and the $\mathrm{C}: \mathrm{N}$ ratio was calculated from the measured values. Concentrations of calcium (Ca), magnesium (Mg), potassium (K) and sulphur (S) were determined with an Inductively Coupled Plasma Optical Emission Spectrometer (iCAP 6200, Thermo Fisher Scientific, Cambridge, UK) after microwave-assisted digestion with nitric acid as previously described by Epie et al. (2014). Total nutrient recycled by incorporating lower stalk into the soil was calculated by multiplying determined mineral concentrations with the biomass yields.

Soluble sugars were determined using the Anthrone method (Trevelyan and Harrison 1952, Bailey 1958). The method was modified as follows: $30 \mathrm{mg}$ of ground sample was extracted six times in $30 \mathrm{ml}$ of $77 \%$ ethanol. In each extraction, the sample was incubated for 60 minutes. The first incubation was at $70{ }^{\circ} \mathrm{C}$ and the subsequent incubations were at room temperature. From the extract, two subsamples of $0.25 \mathrm{ml}$ were taken and $1.25 \mathrm{ml}$ of Anthrone reagent was added. The mixture was boiled for $10 \mathrm{~min}$ and cooled to room temperature. The absorbance was measured at $630 \mathrm{~nm}$ with a spectrophotometer (Shimadzu UV-160 A, Shimadzu Scientific Instruments Inc., Kyoto, Japan). The concentration of water-soluble carbohydrates (WSC) was calculated from the calibration curve based on the absorbance of standard glucose solutions (BDH, Analar).

Total lignin was determined using the Klason Lignin method (Jung et al. 1999, Sluiter et al. 2008). The method was modified as follows: $300 \mathrm{mg}$ of ground sample was extracted in $3 \mathrm{ml}$ of $72 \% \mathrm{H}_{2} \mathrm{SO}_{4}$ (96\%, Suprapur, Merck Emsure) incubated at $30^{\circ} \mathrm{C}$ for $1 \mathrm{~h}$, diluted with deionised water to $4 \%$, and autoclaved at $121^{\circ} \mathrm{C}$ for $1 \mathrm{~h}$. After cooling, the sample volume was raised to $100 \mathrm{ml}$, and vacuum-filtered through a sintered-glass funnel (Sep-Pak Vacuum Manifold, Waters). For analysis of acid soluble lignin (ASL), the hydrolysate was further diluted two-fold with $4 \%$ $\mathrm{H}_{2} \mathrm{SO}_{4}$, and the absorbance was measured at $320 \mathrm{~nm}$ with a spectrophotometer (Shimadzu UV-160 A, Shimadzu Scientific Instruments Inc., Kyoto, Japan). Hydrolysable sugar yield was determined from a subsample of the hydrolysate, which was diluted 50 times with $77 \%$ ethanol and analysed using the modified Anthrone method. The ASL was calculated as,

$$
A S L=\left(U V_{\text {abs }} \times \text { Volume }_{\text {filtrate }} \times \text { Dilution }\right) / \varepsilon \times W_{\text {sample }}
$$

where $\mathrm{UV}_{\mathrm{abs}}=$ sample absorbance

Volume $_{\text {filtrate }}=$ hydrolysate

$\varepsilon=$ absorptivity of maize biomass lignin

$\mathrm{W}_{\text {sample }}=$ sample dry weight

For analysis of acid insoluble lignin (AISL), the solids were dried in an oven $105^{\circ} \mathrm{C}$ for $4 \mathrm{~h}$, cooled in a desiccator, weighed (W1), combusted in a muffle oven at $500^{\circ} \mathrm{C}$ for $24 \mathrm{~h}$, cooled in a desiccator and re-weighed (W2). The AISL content was calculated as W2/W1. The content of hydrolysable sugars was calculated by subtracting the content of soluble sugars from the total sugars. The sugar and lignin yield were calculated based on the dry matter yield.

Data were subjected to analysis of variance (ANOVA) using SPSS version 21 (IBM, Chicago, USA). Data for both years were combined when Levene's test for homogeneity of variance was not significant. Least significant difference (LSD) between lignin and sugar types were determined. Tukey's b test was used to separate treatments, and significance was recognized at $p<0.05$. 


\section{Results}

\section{Biomass yields}

The only one of the four harvests when cultivar showed a significant difference in dry matter yields was that on 22 October 2010, when average yield was also significantly the lowest (Table 2). Maximum dry matter yield in 2010 was obtained from the second harvest on 8 October. Yield was significantly greater in 2011 than in 2010 $(p<0.001)$ (Table 3).

Table 2. Biomass yield of eight maize cultivars harvested on 3 dates in 2010 and one in 2011 in Southern Finland. Data shown are means of 4 replicates.

\begin{tabular}{|c|c|c|c|c|}
\hline \multirow[t]{2}{*}{ Cultivar } & \multicolumn{4}{|c|}{ Biomass yield (t ha-1) } \\
\hline & 23 Sept 2010 & 8 Oct 2010 & 22 Oct 2010 & 20 Oct 2011 \\
\hline Amaretto & 22.1 & 25.6 & 20.3 & 27.9 \\
\hline Campesino & 20.3 & 21.0 & 20.6 & 33.3 \\
\hline Eleganza & 20.1 & 22.3 & 18.5 & 28.8 \\
\hline Fabregas & 19.8 & 19.9 & 18.1 & 27.8 \\
\hline Fernandez & 20.6 & 26.2 & 20.7 & 27.8 \\
\hline Respect & 20.3 & 23.0 & 21.0 & 30.4 \\
\hline Ronaldino & 17.6 & 21.9 & 17.9 & 30.1 \\
\hline Unity & 19.8 & 20.2 & 18.9 & 29.7 \\
\hline S.E. & 1.0 & 1.0 & 1.0 & 1.4 \\
\hline Mean & 20.1 & 22.5 & 19.5 & 29.5 \\
\hline$p$ value & $>0.05$ & $>0.05$ & $<0.01$ & $>0.05$ \\
\hline
\end{tabular}

Table 3. Interactions and significance values of biomass yield, ash content and mineral element composition of eight maize cultivars and their plant fractions in 2010 and 2011

\begin{tabular}{|c|c|c|c|c|c|c|c|c|}
\hline Source of variation & $\begin{array}{l}\text { Biomass } \\
\left(\mathrm{t} \mathrm{ha}^{-1}\right)\end{array}$ & $\begin{array}{l}\text { Ash } \\
(\%)\end{array}$ & $\begin{array}{c}\text { Calcium } \\
\left(\mathrm{g} \mathrm{kg}^{-1}\right)\end{array}$ & $\begin{array}{l}\text { Potassium } \\
\qquad\left(\mathrm{g} \mathrm{kg}^{-1}\right)\end{array}$ & $\begin{array}{l}\text { Magnesium } \\
\quad\left(\mathrm{g} \mathrm{kg}^{-1}\right)\end{array}$ & $\begin{array}{l}\text { Sulphur } \\
\left(\mathrm{g} \mathrm{kg}^{-1}\right)\end{array}$ & $\begin{array}{l}\text { Chloride } \\
\left(\mathrm{g} \mathrm{kg}^{-1}\right)\end{array}$ & $\begin{array}{l}\mathrm{C}: \mathrm{N} \\
\text { ratio }\end{array}$ \\
\hline Year (Y) & $* * *$ & ns & $* * *$ & $* * *$ & $* * *$ & $* * *$ & $* * *$ & ns \\
\hline Cultivar (C) & ns & $* * *$ & $* * *$ & $* * *$ & $* * *$ & $* * *$ & $* * *$ & $* *$ \\
\hline Plant fraction $(\mathrm{P})$ & $* * *$ & $* * *$ & $* * *$ & $* * *$ & $* * *$ & $* * *$ & $* * *$ & $* * *$ \\
\hline $\mathrm{Y} \times \mathrm{C}$ & ns & ns & ns & ns & ns & ns & $* * *$ & ns \\
\hline$Y \times P$ & $* * *$ & $* * *$ & $* * *$ & $* * *$ & $* * *$ & $* * *$ & $* * *$ & $* * *$ \\
\hline$C \times P$ & $* * *$ & ns & $* *$ & $* * *$ & $* * *$ & $*$ & $* * *$ & $* * *$ \\
\hline$Y \times C \times P$ & ns & $*$ & $* *$ & $* *$ & $* *$ & $*$ & $* * *$ & ns \\
\hline
\end{tabular}

\section{Partitioning of yield}

Plant fraction influenced significantly $(p<0.001)$ total biomass yield (Table 3$)$. The ear made up over $50 \%$ of the total plant biomass. Above-ear biomass was generally around $5.0 \mathrm{t} \mathrm{ha}^{-1}$, and mid-stalk biomass around $4.2 \mathrm{t} \mathrm{ha-1}$ (Table 4).

Table 4. Plant portion effect on biomass yield, ash content and mineral element composition of eight maize cultivars showing data of 2010 and 2011 combined

\begin{tabular}{|c|c|c|c|c|c|c|c|c|}
\hline Plant fraction & $\begin{array}{l}\text { Biomass } \\
\left(\text { t ha }^{-1}\right)\end{array}$ & Ash (\%) & $\begin{array}{l}\text { Calcium } \\
\left(\mathrm{g} \mathrm{kg}^{-1}\right)\end{array}$ & $\begin{array}{l}\text { Potassium } \\
\left(\mathrm{g} \mathrm{kg}^{-1}\right)\end{array}$ & $\begin{array}{l}\text { Magnesium } \\
\qquad\left(\mathrm{g} \mathrm{kg}^{-1}\right)\end{array}$ & $\begin{array}{l}\text { Sulphur } \\
\left(\mathrm{g} \mathrm{kg}^{-1}\right)\end{array}$ & $\begin{array}{l}\text { Chloride } \\
\left(\mathrm{g} \mathrm{kg}^{-1}\right)\end{array}$ & $\mathrm{CN}$ ratio \\
\hline Ear & $14.0 \mathrm{~d}$ & $1.8 a$ & $0.2 a$ & $6.6 a$ & $0.9 a$ & $1.1 \mathrm{c}$ & $1.1 a$ & $31 a$ \\
\hline Above-ear & $5.0 c$ & $7.1 \mathrm{~d}$ & $3.8 d$ & $11.4 b$ & $1.4 \mathrm{c}$ & $1.1 \mathrm{c}$ & $1.9 \mathrm{~b}$ & $33 a$ \\
\hline Mid-stalk & $4.2 \mathrm{~b}$ & $5.6 c$ & $3.4 c$ & $14.0 \mathrm{c}$ & $1.4 \mathrm{c}$ & $0.8 b$ & $3.1 \mathrm{c}$ & $46 b$ \\
\hline Lower stalk & $1.7 a$ & $5.0 \mathrm{~b}$ & $2.1 b$ & $13.3 c$ & $1.1 \mathrm{~b}$ & $0.6 a$ & $6.4 d$ & $72 c$ \\
\hline
\end{tabular}

Means within each column with different letters are significantly different at $p<0.05$ according to Tukey $b$ test. 


\section{Plant fractions and their mineral element composition}

There were statistically significant interactions between cultivar and plant fraction for all variables except ash content (Table 3). This indicated that cultivars differed in their allocation of mineral nutrients to the four plant fractions.

Generally, biomass, ash and mineral element composition of the plant fractions were significantly different $(p<$ 0.001 ) (Table 4). Ash content and the concentrations of ash-forming $\mathrm{Ca}, \mathrm{Mg}$ and $\mathrm{Cl}$ were lower in ears than in head and mid-stalk fractions (Table 4). Ash, $\mathrm{Ca}$ and $\mathrm{S}$ were more concentrated in the head fraction than in the mid-stalkfraction. The C:N ratio was highest in the lower stalk followed by the mid-stalk, and low in the head and ear fractions.

\section{Nutrient content of lower stalk}

The yield of $C$ in the lower stalk of the eight cultivars that could be recycled in a hectare of farmland was about $750 \mathrm{~kg}$ (Table 5). The yield of $\mathrm{C}$ in the lower stalk was proportional to the total biomass yield of each cultivar. However, Campesino had significantly more $(p<0.05)$ of $\mathrm{C}$ and $\mathrm{N}$ and correspondingly more $\mathrm{Ca}$ and $\mathrm{K}$ in its lower stalk that could be recycled into the soil.

\begin{tabular}{|c|c|c|c|c|}
\hline Cultivar & Ca $\left(k g h a^{-1}\right)$ & $C\left(\mathrm{~kg} \mathrm{ha}^{-1}\right)$ & $\mathrm{N}\left(\mathrm{kg} \mathrm{ha}^{-1}\right)$ & $\mathrm{K}\left(\mathrm{kg} \mathrm{ha}^{-1}\right)$ \\
\hline Amaretto & 4.0 & $732 a b$ & $12.5 a b$ & 24.7 \\
\hline Campesino & 5.0 & 1095b & $16.1 b$ & 26.7 \\
\hline Eleganza & 3.3 & $727 a b$ & $9.1 \mathrm{ab}$ & 20.8 \\
\hline Fabregas & 4.4 & $724 a b$ & 14.0ab & 28.1 \\
\hline Fernandes & 2.9 & $629 a$ & 8.3ab & 19.8 \\
\hline Respect & 2.6 & $604 a$ & $6.9 a$ & 16.7 \\
\hline Ronaldino & 3.5 & 795ab & $13.8 \mathrm{ab}$ & 30.2 \\
\hline Unity & 3.4 & $705 a b$ & 12.6ab & 15.5 \\
\hline$p$ value & ns & $*$ & $*$ & ns \\
\hline
\end{tabular}

\section{Sugar and lignin content}

Timing of harvest as well as cultivar affected the ASL content (Fig. 1), which was generally highest in the second harvest, and in cv. Ronaldino in all harvests. In contrast, the highest AISL content was measured in the first harvest in all cultivars studied (Fig. 1). The differences between cultivars were significant in both the first and third harvests, with high values in both Campesino and Respect. Total lignin content was highest in the first harvest but there was little difference between cultivars.

Timing of harvest affected the content of soluble sugars, which was maximum in the second harvest in six cultivars and in the third harvest in Amaretto and Fernandez (Fig. 2). Cultivar differences in soluble sugar content were significant only in the third harvest. Hydrolysable sugar content varied depending on timing of harvest and cultivar (Fig. 2). Thus, total sugar yield was highest in the second harvest. Maximum sugar yield was obtained in cultivar Fernandez in the second harvest (Fig. 2). While most cultivars yielded more sugar in the second harvest, Ronaldino did not. All cultivars lost sugar between the second and third harvest. 


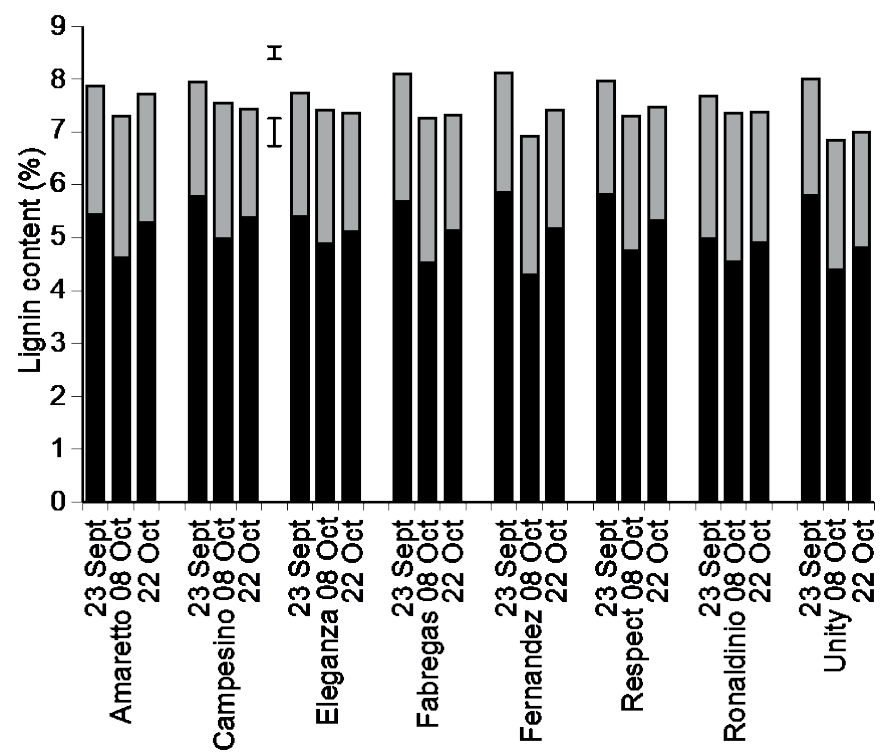

Fig. 1. Acid-insoluble (black bars) and acid-soluble (grey bars) lignin content of 8 cultivars of maize harvested on 3 dates in 2010. Error bars show LSD of (upper bar) acid-soluble and (lower bar) -insoluble lignin.

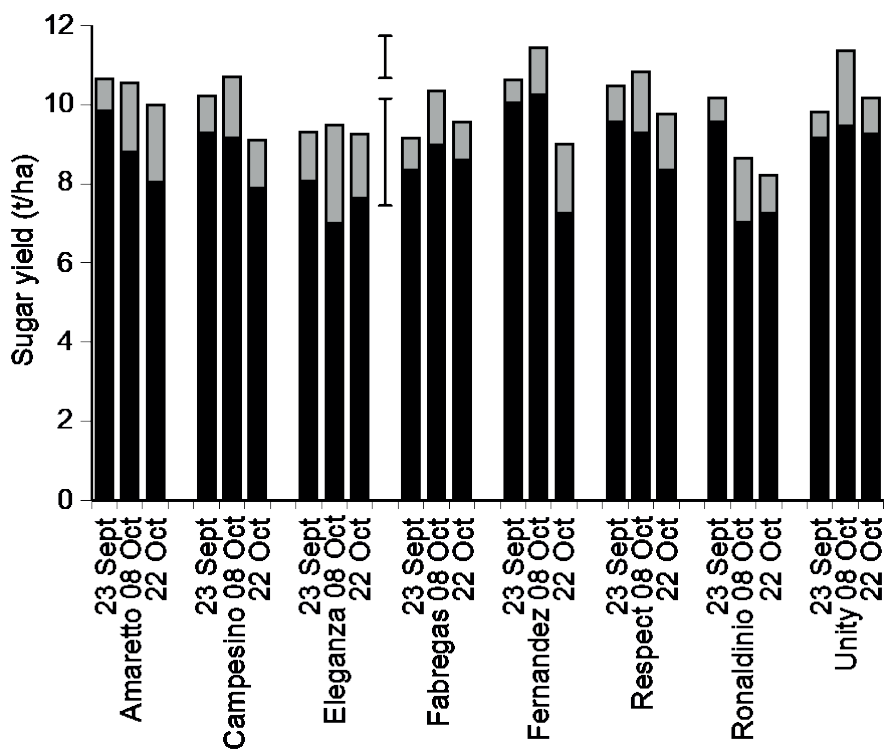

Fig. 2. Hydrolyzable (black bars) and free (grey bars) sugar content of 8 cultivars of maize harvested on 3 dates in 2010. Error bars show LSD of (upper bar) free sugars and (lower bar) hydrolyzable sugars.

\section{Discussion}

\section{Biomass yields}

The eight maize cultivars grew well and generally yielded over $20 \mathrm{t} \mathrm{ha}^{-1}$ of biomass. An earlier study on maize in Southern Finland (Seppälä et al. 2012) reported yields of 10-20 t ha-1. Maize is a C4 crop, a frost-sensitive species that is adapted to warm climates. In this study, the slightly higher temperature and rainfall were associated with $50 \%$ higher yields in 2011 than in 2010. In cool conditions, such as prevail in Finland, a considerable proportion of assimilated carbon can be lost through respiration thereby reducing yields (Miedema 1982). The cultivar difference in whole plant biomass yield was significant only in the late harvest, perhaps indicating that the sensitivity of cultivars to loss of biomass due to late-season chilling differed. Therefore, as Finland and other boreal regions get warmer because of global climate change, feed and biogas cultivars of maize could have the potential to perform well in these parts of the world. Maize could replace reed canary grass, once a popular energy crop in Finland until recently when its use and cropping area decreased (Tike 2014). Future research to test the survivability of a wide range of maize cultivars in high latitudes should be encouraged as this study was limited to only eight cultivars. 
The ears were the most productive plant fraction followed by above-ear, mid-stalk and lower stalk. The biomass distribution compares well to what has previously been reported in literature if cobs and husks that form part of the ear are added in with the grains. Typically, grain accounts for approximately $45-50 \%$ of the total maize plant dry mass (Pordesimo et al. 2005), with a starch content of around 70\% (Negri et al. 2014) which was good for biogas production (Seppälä et al. 2012). The high grain yield is the reason why maize is a major feedstock in the bioethanol industry. The grains are preferred because they are high in easily degradable components and low in ash.

\section{Ash content and mineral element composition}

The mineral composition of maize depends on the crop type, cultivar, cultivation practises, harvest time, and the plant part or fraction analysed (Vassilev et al. 2015). The conversion process for biofuel production is important in determining the desired mineral composition of biomass. The concentrations of some elements should be considered in biofuel production because of their influence on gas emissions, water discharge, and solid waste disposal (Obernberger and Thek 2004). Low ash content and concentrations of ash forming minerals; $\mathrm{K}, \mathrm{Ca}, \mathrm{S}$ and $\mathrm{Cl}$ are desired in biomass intended for thermochemical conversion. High levels of ash reduce hydrocarbon production from this process (Agblevor et al. 1992). During biomass combustion, ash combines with S to produce corrosive sulfates and slag deposits (McLaughlin et al. 1996). Alkali metals K and Ca can react with Si from the residual soil to form alkali silicates and induce operational problems such as 'slag' formation (Vamvuka and Sfakiotakis 2011) that reduce efficiency and increase maintenance costs of CHP systems. A high C:N ratio is preferred in biomass meant for burning, as it confers high calorific value (Obernberger and Thek 2004). Schittenhelm (2008) stated that ash content of plants in general decreases in relation to the progress in maturity resulting in higher ash content in later maturing cultivars than in early maturing cultivars. The present study showed that ash content and mineral element composition differed widely between plant fractions and significantly between cultivars. Ash content and concentrations of some ash-forming minerals, such as $\mathrm{Ca}$ and $\mathrm{S}$ were low in mid-stalk compared to above-ear portions of the plants. Moreover, the mid-stalk fraction had a higher $\mathrm{C}: \mathrm{N}$ ratio than above-ear portions. Thus, the mid-stalk portions of the maize plants are more ideal for use in CHP plants to generate heat and electricity whereas the head fractions are more suited for biogas production. Methane production is optimized within a C:N ratio of 10-30 (Amon et al. 2007) and is strongly dependent on biomass composition (Oslaj et al. 2010). It is important to understand the variation in mineral element composition and fuel characteristics to manage and overcome problems during the conversion of biofuel in the bioenergy industry. The choice of bioenergy conversion system for maize stalks is thus open and depends on the available technology.

\section{Nutrients in lower stalk}

This study showed that the lower $20 \mathrm{~cm}$ of the harvestable part of the maize plants contained about three quarters of a ton of $C$, and it is reasonable to assume that the bottom (unharvested) $10 \mathrm{~cm}$ would contain about half that, making a total of over 1 ton of organic carbon that could be recycled into the soil. Many management practices sequester less than a ton of $C$ per hectare annually (Chan et al. 2009), whereas an annual plant $C$ input of $1.2 \mathrm{t} \mathrm{ha}^{-1}$ is needed in order to maintain a constant soil organic $\mathrm{C}$ content through time (Li and Feng 2002). Since the biomass also contained $\mathrm{Ca}, \mathrm{K}, \mathrm{Mg}, \mathrm{S}$, and $\mathrm{Cl}$, harvesting of the ears, above-ear and mid-stalk fractions of the maize plant from the fields, as done in this study would likely increase the depletion of soil nutrients. Harvesting solely the ears removed 9 to $12 \%$ less N, P, K, and S than the harvest of both stubble and ears, and thus depleted soil nutrients at slower rate (Sindelar et al. 2013). To overcome the problem of nutrient mining, this study suggests that about $30 \mathrm{~cm}$ of the lower stalk be left in the field after harvest to maintain soil organic matter and nutrient contents. Similarly, Hoskinson et al. (2007) recommended that $40 \mathrm{~cm}$ of maize stalk should be left in the field.

\section{Sugar and lignin content}

Cultivars with high proportions of ASL had the least percentage of AISL and the same trend with the harvest dates. The complexity of cell wall structure and degradability, and effects on acid lignin solubility, makes it difficult to understand how these factors finally influence AISL. Nevertheless, the reduction of the AISL during the harvesting dates could be explained with these factors (Grabber 2005). For most cultivars, there was a measurable advantage in sugar yield from a slightly delayed harvest (early October instead of late September). The small but significant reduction in lignin content, mostly in the acid-insoluble fraction, achieved by slightly delaying the harvest represents an increase in feedstock quality for bioenergy purposes. Cultivars with less lignin produced more sugar in accordance with conclusions (Brown 1985, Jung and Deetz 1993) that the feedstock with less lignin content produces more sugar; lignin restricts the degradability of structural polysaccharides by hydrolytic enzymes and thus the sugar production. However, other studies indicate that some variations in the lignin structure, composition and/or cross-linking to other matrix components are more implicated in the degradability than the amount of lignin (Jung and Deetz 1993, Grabber 2005). 


\section{Conclusions}

Several crops have been evaluated for energy production but there are few studies that assess the possibility to harvest separately, the different plant fractions of maize for energy use. Based on the results of this study, these forage maize cultivars can grow well in southern Finland especially during warmer growing seasons and their plant fractions could be separated and used for energy purposes. The ears could be harvested for bioethanol or livestock feed and the stalks used for either biogas or CHP. The bottom $30 \mathrm{~cm}$ of the stalk could be recycled into farmland to improve soil organic carbon content. Multi-purpose maize cultivars could contribute to energy generation without affecting either the food supplies or the environment and same time have an added value for farmers. The study revealed that from the same maize plant, a solid, liquid or gas forms of energy can be obtained while recycling nutrients, especially carbon into the soil. This study adds to the basic knowledge on composition and properties of biomass and suggest the possible application of this knowledge for an environmentally safe use.

\section{Acknowledgments}

The Department of Agricultural Sciences Sciences, University of Helsinki, Finland and the Academy of Finland are gratefully acknowledged for their financial supports. Markku Tykkyläinen and Marjo Kilpinen are acknowledged for their invaluable field and laboratory assistance. We also wish to thank the anonymous reviewers for their critical contributions.

\section{References}

Agblevor, F.A., Rejai, B., Evans, R.J. \& Johnson, K.D. 1992. Pyrolytic analysis and catalytic upgrading of lignocellulosic materials by molecular beam mass spectrometry. In: Klass, D.L. (ed.). Energy from Biomass and Wastes XVI. Chicago: Elsevier Applied Science Publications. p. 69-75.

Amon, T., Amon, B., Kryvoruchko, V., Zollitsch, W., Mayer, K. \& Gruber, L. 2007. Biogas production from maize and dairy cattle manure-Influence of biomass composition on the methane yield. Agriculture Ecosystems and Environment 118: 173-182. https:// doi.org/10.1016/j.agee.2006.05.007

Bailey, R.W. 1958. The reaction of pentoses with Anthrone. Biochemistry Journal 68: 669-672. https://doi.org/10.1042/bj0680669

Barros-Rios, J., Romani, A., Garrote, G. \& Ordas, B. 2015. Biomass, sugar and bioethanol potential of sweet corn. GCB Bioenergy 7: 153-160. https://doi.org/10.1111/gcbb.12136

Bennett, A.S., Bern, C.J., Richard, T.L. \& Anex, R.P. 2007. Corn grain drying using corn stover combustion and CHP systems. Transactions of the ASABE 50: 2161-2170. https://doi.org/10.13031/2013.24076

Brown, A. 1985. Review of lignin in biomass. Journal of Applied Biochemistry 7: 371-87.

Byrt, C.S., Grof, C.P.L. \& Furbank, R.T. 2011. C4 plants as biofuel feedstocks: optimizing biomass production and feedstock quality from a lignocellulosic perspective. Journal of Integrative Plant Biology 53: 120-35. https://doi.org/10.1111/j.1744-7909.2010.01023.x

Chan, K.Y., Cowie, A., Kelly, G., Bhupinderpal Singh \& Slavich, P. 2009. Soil organic carbon sequestration potential for agriculture in NSW. NSW DPI Science \& Research Technical paper. 28 p.

Chen, M., Kaur, P., Dien, B., Below, F., Vincent, M.L. \& Singh, V. 2013. Use of tropical maize for bioethanol production. World Journal of Microbiology and Biotechnology 29:1509-1515. https://doi.org/10.1007/s11274-013-1317-1

Doran, J.W. 2002. Soil health and global sustainability: translating science into practice. Agriculture Ecosystem and Environment 88: 119-127. https://doi.org/10.1016/S0167-8809(01)00246-8

Epie, K.E., Virtanen, S., Santanen, A., Simojoki, A. \& Stoddard, F.L. 2014. The effects of permanently elevated water table in an acid sulphate soil on reed canary grass for combustion. Plant and Soil 375: 149-158. https://doi.org/10.1007/s11104-013-1925-4

Farrell, A.E., Plevin, R.J., Turner, B.T., Jones, A.D., O’Hare, M. \& Kammen, D.M. 2006. Ethanol can contribute to energy and environmental goals. Science 311: 506-508. https://doi.org/10.1126/science.1121416

Feil, B., Moser, S.B., Jampatong, S. \& Stamp, P. 2005. Mineral composition of the grains of tropical maize varieties as affected by pre-anthesis drought and rate of nitrogen fertilization. Crop Science 45: 516-523. https://doi.org/10.2135/cropsci2005.0516

FMI 2017. Finnish Meteorological Institute 2017. http://en.ilmatieteenlaitos.fi/climate. Accessed 21 October 2017.

Grabber, J.H. 2005. How do lignin composition, structure, and cross-linking affect degradability? A review of cell wall model studies. Crop Science 45: 820-831. https://doi.org/10.2135/cropsci2004.0191

Hoskinson, R.L., Karlen, D.L., Birrell, S.J., Radtke, C.W. \& Wilhelm, W.W. 2007. Engineering, nutrient removal, and feedstock conversion evaluations of four corn stover harvest scenarios. Biomass and Bioenergy 31: 126-136. https://doi.org/10.1016/j.biombioe.2006.07.006

Huggins, D.R., Buyanovky, G.A., Wagner, G.H., Brown, J.R., Darmody, R.G., Peck, T.R., Lesoing, G.W., Vanotti, M.B. \& Bundy, L.G. 1998. Soil organic $C$ in the tallgrass prairie-derived region of the corn belt: effects of long-term crop management. Soil Tillage Research 47: 219-234. https://doi.org/10.1016/S0167-1987(98)00108-1

Jung, H.G. \& Deetz, D.A. 1993. Cell wall lignification and degradability. In: Jung, H.G., D.R. Buxton, D.R., Hatfield , R.D. \& Ralph, J. (eds.). Forage Cell Wall Structure and Digestibility. Madison, Wisconsin: ASA-CSSA-SSSA. p. 315-346. https://doi.org/10.2134/1993. foragecellwall.c13 
Jung, H.G., Varel, V.H., Weimer, P.J. \& Ralph, J. 1999. Accuracy of Klason lignin and acid detergent lignin methods as assessed by bomb calorimetry. Journal of Agriculture and Food Chemistry 47: 2005-2008. https://doi.org/10.1021/jf981250q

Kukk, L., Astover, A., Roostalu, H., Rossner, H. \& Tamm I. 2010. The dependence of reed canary grass (Phalaris arundinacea L.) energy efficiency and profitability on nitrogen fertilization and transportation distance. Agronomy Research 8: 123-133.

Larsen, J.A. 1980. The Boreal Ecosystem. London: Academic Press. p. 47-89. https://doi.org/10.1016/B978-0-12-436880-4.50008-X Li, X. \& Feng, Y. 2002. Carbon Sequestration Potentials in Agricultural Soils. Alberta Research Council: Edmonton, Alberta. 11 p. Lötjönen, T. \& Paappanen, T. 2013. Bale density of reed canary grass spring harvest. Biomass and Bioenergy 51: 53-59. https:// doi.org/10.1016/j.biombioe.2012.12.041

Mäkelä, P., Munns, R., Colmer, T.D. \& Peltonen-Sainio, P. 2003. Growth of tomato and an ABA-deficient mutant (sitiens) under saline conditions. Physiology Plantarum 117: 58-63. https://doi.org/10.1034/j.1399-3054.2003.1170107.x

Masters, M.D., Black, C.K., Kantola, I.B., Woli, K.P., Voigt, T., David, M.B. \& DeLucia, E.H. 2016. Soil nutrient removal by four potential bioenergy crops: Zea mays, Panicum virgatum, Miscanthus $X$ giganteus, and prairie. Agriculture Ecosystem and Environment 216: 51-60. https://doi.org/10.1016/j.agee.2015.09.016

McLaughlin, S.B., Samson, R., Bransby, D. \& Wiselogel, A. 1996. Evaluating physical, chemical, and energetic properties of perennial grasses as biofuels. In: Bioenergy '96. Proceedings of the Seventh National Bioenergy Conference. September 15-20, Nashville Tennessee. V.1. p. 1-8.

Miedema, P. 1982. The effect of low temperature on Zea mays. Advances in Agronomy 35: 93-128. https://doi.org/10.1016/ S0065-2113(08)60322-3

Mokma, D.L., Yli-Halla, M. \& Hartikainen, H. 2000. Soils in a young landscape on the coast of southern Finland. Agricultural and Food Science in Finland 9: 291-302. https://doi.org/10.23986/afsci.5670

Negri, M., Bacenetti, J., Manfredini, A., Lovarelli, D., Fiala, M., Maggiore, T.M. \& Bocchi, S. 2014. Evaluation of methane production from maize silage by harvest of different plant portions. Biomass and Bioenergy 67: 339-346. https://doi.org/10.1016/j.biombioe.2014.05.016

Obernberger, I. \& Thek, G. 2004. Physical characterisation and chemical composition of densified biomass fuels with regard to their combustion behaviour. Biomass and Bioenergy 27: 653-69. https://doi.org/10.1016/j.biombioe.2003.07.006

Oslaj, M., Mursec, B. \& Vindis, P. 2010. Biogas production from maize hybrids. Biomass and Bioenergy 34: 1538-1545. https:// doi.org/10.1016/j.biombioe.2010.04.016

Pakarinen, A., Maijala, P., Stoddard, F.L., Santanen, A., Tuomainen, P., Kymäläinen, M. \& Viikari, L. 2011. Evaluation of annual bioenergy crops in the Boreal zone for biogas and ethanol production. Biomass and Bioenergy 35: 3071-3078. https://doi. org/10.1016/j.biombioe.2011.04.022

Peltonen-Sainio, P., Venäläinen, A., Mäkelä, H.M., Pirinen, P., Laapas, M., Jauhiainen, L., Kaseva, J., Ojanen, H., Korhonen, P., Huusela-Veistola, E., Jalli, M., Hakala, K., Kaukoranta, T. \& Virkajärvi, P. 2016. Harmfulness of weather events and the adaptive capacity of farmers at high latitudes of Europe. Climate Research 67: 221-240. https://doi.org/10.3354/cr01378

Pordesimo, L.O., Hamea, B.R., Sokhansanj, S. \& Edens, W.C. 2005. Variation in corn stover composition and energy content with crop maturity. Biomass and Bioenergy 28: 366-374. https://doi.org/10.1016/j.biombioe.2004.09.003

Sage, R.F. 2004. The evolution of C4 photosynthesis. New Phytologist 161: 341-370. https://doi.org/10.1111/j.14698137.2004.00974.x

Schittenheim, S. 2008. Chemical composition and methane yield of maize hybrids with contrasting maturity. European Journal of Agronomy 29: 72-79. https://doi.org/10.1016/j.eja.2008.04.001

Seleiman, M.F., Santanen, A., Jaakkola S., Ekholm P., Hartikainen, H., Stoddard F.L. \& Mäkelä P.S.A. 2013. Biomass yield and quality of bioenergy cropsgrown with synthetic and organic fertilizers. Biomass and Bioenergy 59: 477-485. https://doi.org/10.1016/j. biombioe.2013.07.021

Seppälä, M., Pyykkönen, V., Laine, A. \& Rintala, J. 2012. Methane production from maize in Finland - Screening for different maize varieties and plant parts. Biomass and Bioenergy 46: 282-290. https://doi.org/10.1016/j.biombioe.2012.08.016

Sindelar, A.J., Lamb, J.A., Sheaffer, C.C., Rosen, C.J. \& Jung, H.G. 2013. Fertilizer nitrogen rate effects on nutrient removal by corn stover and cobs. Agronomy Journal 105: 437-445. https://doi.org/10.2134/agronj2012.0240

Sluiter, A.D., Hames, B., Ruiz, R.O., Scarlata, C.J., Sluiter, J.B., Templeton, D.W. \& Crocker, D. 2008. Determination of structural carbohydrates and lignin in biomass. Laboratory analytical procedure. National Renewable Energy Laboratory. http://www.nrel.gov/ biomass/analytical_procedures.html.p. 1-14.

Tike 2014. Agricultural Statistics, http://www.maataloustilastot.fi/en/utilisedagricultural-area. Accessed 20 June 2014.

Trevelyan, W.E. \& Harrison, J.S. 1952. Studies on yeast metabolism. 1. Fractionation and micro determination of cell carbohydrates. Biochemistry Journal 50: 298-303. https://doi.org/10.1042/bj0500298

Wilhelm, W.W., Johnson, J.M.F., Hatfield, J.L., Voorhees, W.B. \& Linden, D.R. 2004. Crop and soil productivity response to corn residue removal: a literature review. Agronomy Journal 96: 1-17. https://doi.org/10.2134/agronj2004.0001

Vamvuka, D. \& Sfakiotakis, S. 2011. Effects of heating rate and water leaching of perennial energy crops on pyrolysis characteristics and kinetics. Renewable Energy 36: 2433-2439. https://doi.org/10.1016/j.renene.2011.02.013

Vassilev, S.V., Vassileva, C.G. \& Vassilev, V.S. 2015. Advantages and disadvantages of composition and properties of biomass in comparison with coal: An overview. Fuel 158: 330-350. https://doi.org/10.1016/j.fuel.2015.05.050 